\title{
BALANCING SOCIO-ECONOMIC DEVELOPMENT OF UKRAINE' REGIONS ON THE PRIORITY OF THE SOCIO-HUMANITARIAN POTENTIAL' EFFICIENT CAPITALIZATION
}

\section{Bogush Larysa ${ }^{1}$}

DOI: http://dx.doi.org/10.30525/978-9934-571-28-2_4

\begin{abstract}
The purpose of the study is to substantiate the approaches and priorities, to determine the prospects for balancing the socio-economic development of the Ukraine' regions through the systematic realization of the national socio-humanitarian resources. Methodology. The experience of their reproduction and effective capitalization in the process of balancing and mitigating territorial disparities in the countries worldwide has approved regional policy, acceptable for dissemination in Ukraine. Along with this, the methodological basis for studying the social aspects and guidelines of the development of the Ukrainian economy' regional subsystems consists of numerous works on: problems of increasing the efficiency of system management by a set of social processes; diversifying the employment sphere, balancing supply and demand in the labor market, adjusting the property stratification of the economically active population; improvement of mechanisms for satisfying its socially necessary needs; solving acute problems of optimization of start-up opportunities and social protection. Conclusions. The social orientation of economy' regional subsystems is an essential condition for establishing the pace and optimizing the proportions of state development, as it ensures the proper reproduction and growth of its human, vocational, qualification and innovation potential, supports the social harmony foundations, stimulates social responsibility of business and implementation of humanistic management concepts. The main criteria for the Ukrainian regional policy' quality include: the level and tendencies of diversification of economic complexes in accordance with the regional resource potential and the need to strengthen their science-intense and innovative orientation, as well as the level of formation and results of functioning of the regional
\end{abstract}

\footnotetext{
${ }^{1}$ Candidate of Economic Sciences, Senior Researcher, Leading Researcher,

Ptoukha Institute for Demography and Social Studies

of the National Academy of Sciences of Ukraine, Ukraine
} 
closed-loop production clusters; the level and dynam-ics of the population differentiation by characteristics of property, income and expenses; dynamics of medical and demographic characteristics of local and regional communities; availability and quality of satisfaction of their living, social and cultural needs in terms of socially necessary and private components; the level of ecological safety of the local and regional communities' living environment, including in the context of closer and remote prospects of resource development and economic use of territories. The balance of regional policy for reproduction and efficient capitalization of the socio-humanitarian potential should be achieved through the implementation of the quantitative and qualitative state obligations regarding: the ensuring a decent level and a safe liv-ing environment of the population; stimulation of its productive employment; intervention in the development of regions and local communities in order to optimize the reverse influences on the whole country' activity due to the negative dynamics of the monitoring indicators' system.

\section{Introduction}

The social orientation of economy and its regional subsystems is an essential condition for establishing the pace and optimizing the proportions of state development, as it ensures the proper reproduction and growth of its human, vocational, qualification and innovation potential, supports the foundation of social harmony, stimulates social responsibility of business and implementation of humanistic management concepts. The consolidation of the socially oriented market economy in the Ukrainian regions is based on the stabilization and expansion of the labor market, the growth of intellectual, professional and qualification potential, the promotion of productive em-ployment, the application of reasonable standards in the normalization of the foundations of the population social protection, the development of regulating and controlling civil society institutions.

Therefore, the purpose of the study is to substantiate the approaches and priorities, as well as to determine the prospects for balancing the socio-economic development of the Ukraine' regions through the systematic realization of the national socio-humanitarian resources in the spectrum of their human, intellectual, innovative, communicative, organizational, interface components [2, p. 103-112].

The experience of their reproduction and effective capitalization in the process of balancing and mitigating territorial disparities in the countries 
worldwide has formed a significant part of the approved regional policy, acceptable for dissemination in Ukraine [1; 5, p. 11-15; 6; 11; 13, p. 57-71]. Along with this, the methodological basis for studying the social aspects and guidelines of the current and future development of the Ukrainian economy' regional subsystems consists of numerous works on: problems of increasing the efficiency of system management by a set of social processes $[4$, p. 51-57; 5, p. 11-15; 7, p. 12-26; 9, p. 103-107]; diversifying the employment sphere, balancing supply and demand in the labor market and adjusting the property stratification of the economically active population $[3$, p. $4-10 ; 7$, p. $102-138 ; 8$, p. 74-76; 10, p. 97-102]; improvement of mechanisms for satisfying its socially necessary needs [4, p. 51-57; 7, p. 206-244; 13, p. 178-239]; solving acute problems of optimization of start-up opportunities and social protection [8, p. 74-76; 9, p. 103-107; 15 , p. 57-66]. Experts have proved the dependence of economic performance and perspectives of regional sustainable development on the systematic implementation of existing guarantees in the field of reproduction of human capital and labor supply, as well as on the competitiveness of employed and economic entities [5; 12, p. 4-8; 13, p. 345-406, 515-556; 14; p. 63-66], which in turn is primarily related to the territorial conditions of improvement and realization of their professional, qualification, entrepreneurial and innovative potential.

\section{Implementation of the developed countries' experience in balancing Ukrainian regional disparities}

Approaches and trends in the development and implementation of regional policy in countries that today are characterized by the most financial, economic, social and political stability, combine: reduction of regional socioeconomic imbalances by redistributing resources between developed, depressed and crisis territories; provision of social equity through targeted support for regions parity based on the main social indicators; formation and improvement of the effectiveness of the adaptation mechanisms of the backward and other problematic regions to changes in the organizational and economic mechanism in the current period of socio-economic development.

Among the important measures within the first main direction of the policy for balancing regional disparities we should note: direct state interference in the regions activity in order to equalize their quantitative socio-economic characteristics, including on the basis of structural adjustment and 
strengthening the complexity of territorial economies; stimulation of the large enterprises construction in the basic specialization sectors, including those with a significant share of state capital; targeted investment in infrastructure and public works; stimulation of territorial workforce mobility; provision of privileges, loans and grants to economic entities in the specialization sectors of the backward regions; establishment of tax and financial incentives for national and foreign investors in the economy of these regions and free economic zones.

The implementation of the second of aforementioned directions takes place primarily due to:

- decentralization of decision-making and a balanced division of powers between the center and the regions based on:

- the subsidiarity (i.e., the preservation under central government of the general planning functions and those social ones that are not capable to organize adequately by local authorities, in conjunction with the formation of fiscal and tax relations system, guaranteeing the resources provision of functions assigned to territorial bodies of a certain level);

- the increase of the responsibility of sub-national (municipal, regional) authorities for defining the directions and perspectives of territorial communities sustainable development on the basis of raising the level of their financial provision with local resources;

- the control over the compliance of decisions and financial transactions of local administrations with the national legal and regulatory framework;

- involvement of self-development incentives of regions and territorial communities related to reserves of natural and manpower resources, organizational technologies, in particular by:

- optimizing their educational policy, including on the basis of: conducting training, advanced training and retraining of personnel at production facilities; developing training for new technologies, subsidizing scientific activity, as well as entrepreneurship in the field of various scientific services and higher management; involving higher educational institutions to the regional programs for $\mathrm{R} \& \mathrm{D}$, environmental protection, preparation of technical and technological justifications for the development of the territory and the construction of separate objects, fulfillment of labor resources' planned training financed from local budgets;

- stimulating the creation and application of science-intensive technologies, including through the support of small high-tech firms, the formation 


\section{Bogush Larysa}

of innovative complexes, centers for the advanced technologies' dissemination, techno-parks at higher educational institutions and techno-polises in places of science-intensive industries' concentration;

- encouraging small and medium-sized enterprises in the service sector;

- increasing economic efficiency of use of natural recreational potential, historical and cultural heritage in regions where natural conditions allow to develop tourism as a branch of specialization of local and national economies.

Consequently, the main criteria for the Ukrainian regional policy' quality include: the level and tendencies of diversification of economic complexes in accordance with the regional resource potential and the need to strengthen their science-intense and innovative orientation, as well as the level of formation and results of functioning of closed-loop production clusters in the regional economies; the level and dynamics of the population differentiation by characteristics of property, income and expenses; dynamics of medical and demographic characteristics of local and regional communities in general; availability and quality of satisfaction of their living, social and cultural needs in terms of socially necessary and private components; the level of ecological safety of the living environment of local and regional communities, including in the context of closer and remote prospects of resource development and economic use of territories.

\section{Positives and problems of Ukraine' territorial development in the context of its socio-humanitarian potential' reproduction and realization}

According to the aforementioned quality criteria, the results of the implementation of Ukraine' regional policy (as an integral part of the public administration of socio-economic development) in the last decade acquire ambiguous assessments. Positive effects and trends of the regional development, in particular, include: the decentralization of social powers and obligations, that has been already started; the local projects on the revival and improvement of the infrastructure of preschool and secondary education, health care, culture; the further development of the organizational and economic mechanism for providing socially necessary services on the basis of compulsory insurance; the realization of a number of different scale projects for modernization and further development of road, transport and communal infrastructure; the financial, tax, informational and methodical stimulation of regional and local 
initiatives aimed at revitalizing the entrepreneurial activity of the population in the areas of small-scale agricultural production, processing industry, individual housing construction, services, tourism.

Along with them, it should be noted a number of negatives and threats, among which:

- ineffectiveness of the state policy regarding the innovation transformation of regional economic complexes, including in terms of ensuring the corresponding specialization of the free economic zones, stimulating the formation of territorial clusters in services and innovation infrastructure;

- permanent shortage of budgetary resources for providing the socially necessary living, social and cultural needs of the population (the definition of the latter is carried out practically without taking into account sectoral standards and norms, only on the basis of the financing practice in the short-term retrospective, and recently - exclusively on the actual budget provision), as well as for the complete infrastructure modernizing and maintaining the staff of the territorial communities' institutions of social purpose, which is exacerbated on the local budgets' level, including newly created integrated communities;

- instability of mechanisms and situational practice of subsidizing relevant items of regional and other local budgets expenditures, as well as of distributing these funds at the local communities level;

- low level of financing of state and regional programs for: controlling the sanitary and epidemiological situation; preventing morbidity among the population of pre-working and working age; renovating engineering networks and complying the requirements of the economy' ecological safety;

- inefficiency of mechanisms of state control over the conditions of employment and labor remuneration at non-state enterprises, as well as in non-standard labor relations in general.

Important factors of low efficiency of Ukraine' regional policy remain as follows:

- insufficient consistency and numerous problems of implementation of legal and regulatory framework of the population social protection (in particular, as to the Law of Ukraine of 5.10.2000 No. 2017-III "On state social standards and state social guarantees"). Multifacetedness of government obligations concerning social security and protection, outlined in this act and stipulated by it State classifier of social standards and criteria, still has not been duly accounted in methods of determination of the minimum living wage and other financial guarantees. Valid method of minimum living 


\section{Bogush Larysa}

wage calculation rather weakly accounts the content of its social component (as a value representation of a range of needs in cultural and educational, medical, recreational and other goods and services, consumption of which provides proper quality of individual and territorial social reproduction). The delay in development and adaptation of state social standards at the regional level leads to the imbalance of legal guarantees and budget commitments, the approval of financially weak and mutually reinforcing state and regional programs, contributes to the subjective distribution of available resources by authorities at different levels and their non-targeted use;

- conjunctural mechanisms for identifying priority measures of state social policy and their implementation at the regional level, which is reflected in the dispersion of the relevant resource supply, inadequate consideration of the needs of specific territorial communities;

- efficiency deterioration of the social mechanisms of vertical social mobility and cultural and ideological integration;

- insufficient development of the legal and regulatory framework for the development of the social services market, as well as the inconsistency between the proposed mechanisms for the accumulation of extra-budgetary resources for providing the needs in housing, health care, vocational education, on the one hand, and the financial and property realities of the population' most stratums, on the other;

- numerous deficiencies of the consumer rights protection mechanism, con-nected with inappropriate development and lack of coordination of sectoral legislation in the field of the individual demand service.

The analysis of the volumes and production structure of gross added value in the Ukrainian regions reflects a marked increase in the substantial territorial differentiation of economic potential, generally indicating:

- the inefficiency of the state policy concerning: innovative transformation of the regional economic complexes, including the provision of appropriate specialization of free economic zones, stimulation of the formation of services and innovation infrastructure' territorial clusters; assistance to the depressed regions development (primarily ones with surplus labor resources and traditional agricultural specialization, as well as other areas of monospecialization and increased technogenic risks);

- the shortcomings in the regulation of the Ukrainian fiscal system, which are manifested in the taxation at the location of the companies' central offices rather than production locations directly; 
- the low proportion of closed-loop productions in combination with a significant level of the regional economies' shadow sectors;

- specialization of the economy as a whole on the export of raw materials and semi-finished products, as well as on transit.

A rather close correlation between the volumes of gross regional product, gross added value and the level of incomes, wages and expenditures of the Ukrainian regions' population (first of all, in the "obligatory" articles of payment for housing, communal and transport services) plays a significant direct and indirect role (related to the potential of filling the local and regional budgets, the level of their subsidizing from the state budget, and therefore - the scale of expenditures for providing social needs and developing infrastructure) in the formation and maintaining a spatial parameters of unjustified social inequality, as well as the social and individual factors and mechanisms for limiting or stimulating educational and labor migrations, other active measures for ensuring productive employment and vertical social mobility of the population.

\section{Essential social priorities of the Ukraine' regional policy on the medium-term prospect}

The Ukraine' regional policy for the medium-term period includes the main directions for: balancing the territorial and sectoral proportions of the regional development, confirming the post-industrial and social orientation of their economies, stimulating consumer demand as the driving force of economic growth, optimizing the general conditions of social reproduction in general; increasing the investment volume of regional clusters of science-intense and high-tech industries and their output, improving innovation activity in all economy spheres, management and public life; ensuring a decent life quality of the population (primarily on the basis of full implementation of legally regulated human rights as guarantees of equal access to socially necessary goods and services, optimization of the parameters of vulnerable strata' targeted social protection), creating conditions for the harmonious development of territorial communities and individuals; balancing the proportions and interactions of the spectrum of life activity forms (labor, consumer, reproductive, socio-ecological) of the population in regions and settlement systems; providing the territorial communities' development based on the principles of self-governance and establishment of the civil society' regulating institutions; 


\section{Bogush Larysa}

maintaining the set of principles and parameters on the key aspects of the national security.

In this context, the hierarchy of challenges for Ukraine' regional policy at the current stage of socio-economic development includes:

- the urgency of formation and implementation of a holistic system of social standards and guarantees designed to ensure the proper quality of the population' reproduction and life, as well as methods and mechanisms for their adaptation, implementation and correction at the regional and local levels;

- the requirement of balancing the volumes and establishing the mechanisms for financing expenditures of the local and regional budgets for providing socially necessary living and intangible needs of the population;

- the importance of ensuring effective control and adjustment of negative changes and threats of the sanitary-epidemiological, demographic and migration situation' complication;

- the need to increase the efficiency of mechanisms for stimulating productive employment of the population in the settlement systems within the framework of measures presented by relevant national and regional programs, financial, methodical (both organizational and informational) initiatives of employment services, employers, entrepreneurial structures, voluntary public associations;

- the expediency of targeted adjustment of the investment climate in the regional and local entities of territorial division by regulatory, fiscal, program and administrative measures;

- the importance of maintaining social harmony and stability, in particular, in its socio-political, cultural and ideological, interethnic, inter-confessional aspects;

- the need to optimize the methods of determining the problem territories' main types (depressive, backward, crisis, areas of special functional or problem orientation, areas of special economic modes), the procedures for monitoring the systems of their socio-economic characteristics, as well as the mechanisms of rehabilitation, including on the basis of: implementing joint programs of mutually beneficial development of problem and advanced regions; establishing local growth points in the branches of processing industry, which operates on the local raw materials, services and tourism, the modern technologies and innovative support of entrepreneurial activity; 


\section{Balancing socio-economic development of Ukraine' regions on the priority...}

- the urgency of improving mechanisms for solving acute social problems of territorial development, in particular, regarding provision of opportunities for vertical social mobility of the population, prevention of its marginalization, adaptation of youth in society and in the labor market.

The most important problems that urgently require a systemic solution (with using an integrated program approach and indicative planning) in order to optimize the regional socio-economic development' proportions and to activate the advantageous growth opportunities (particularly in social subsystem), include:

- structural reorganization and modernization of the housing stock, housing and communal services, scientific and educational complex, recreational and entertainment industry, health protection sector; improvement of ecological safety of the housing, communal and recreational sectors, as well as natural and anthropogenic (household, industrial) environment of the population vital activity;

- improvement of the investment climate and competitive environment in the sectors for producing domestic goods and services of social purpose; regulation of their domestic market and competitiveness on the basis of ensuring proper quality control, as well as accessibility, taking into account legislative guarantees and dynamics of the population solvent demand;

- strengthening and increasing the economic efficiency of the use of scientific, technical, socio-economic and natural potential of export-oriented sectors for the production of social services (primarily, in vocational education, specialized medical care, sanatorium and resort recreation, tourism, exhibition activities);

- increasing the contribution of education to the economy modernizing on the basis of forming the system of life-long education, updating the content and optimizing the structure of vocational education, optimizing the mechanisms for providing the needs of regional economic complexes in the specialists and skilled workers' training, forming the territorial clusters of venture production based on innovations and start-ups in educational and scientific services;

- preservation and improvement of qualitative characteristics of human and other components of social capital, including on the basis of: restoring the stimulating function of remuneration in the budget sector and lowpaid types of the social purpose' economic activities of the other ownership forms; increasing the solvency and optimizing the level of social protection 
of the middle- and low-income population groups; overcoming organizational and economic problems and territorial deformations in the household-providing, consumer-providing and socio-cultural sectors' functioning, in particular, regional problems of forming and functioning the basic social infrastructure in the settlement systems;

- balancing the demand and supply of specialists and skilled workers in regional labor markets, ensuring productive employment of economically active population, as well as social protection of employees in the non-state sector of the economy.

\section{Measures on the socio-humanitarian potential' reproduction and realization in the strategy for stimulating the problem territories' development}

An indispensable component of the Ukraine' socio-economic development strategy is the regulation of territorial disparities by stimulating the "growth points" in the economy, areas of employment and social protection of problem regions. The latter ones include the following main types of territories:

- depressive - territories that until recently have been relatively well devel-oped and still have a significant potential for socio-economic characteristics' stabilization, but for global and national reasons (for example, due to the impact of radical market and socio-political reforms), became in the systemic crisis characterized by a sharp (compared with pre-crisis period) reduction of indicators of the economy and social sphere' development;

- backward - territories that are characterized by the low (in the background of other regions of the country that are more or less progressive) level of the socio-economic indicators during the long period measured by decades (i.e., chronically);

- crisis - territories of any level of development (average, low, high) that have undergone significant technological or ecological disasters, which, for more or less long time, have destroyed the usual way of life, or even have prevented the economic complex' functioning, or have affected adversely on the opportunities of ensuring its effectiveness measured like in the pre-crisis period;

- territories of a special functional or problem orientation - subjects of administrative-territorial division that are closed to free access now or have been closed previously (from cantonments to the places of compact 


\section{Balancing socio-economic development of Ukraine' regions on the priority...}

placement of regime-based science-intensive industries and other similar objects), areas of ethnic minorities' compact residence, nature reserve fund objects and territories of special protection (including sanitary protection districts of resorts and other recreational zones);

- areas of special economic modes (including foreign economic activity) - special economic zones, technoparks, technopolises, etc.

The main directions for stimulating the development and support of these economically less developed and depressed territories, in particular, combine:

- the implementation of a set of measures to ensure the progress and modernization of the regional economies structure through fiscal, program and administrative stimulation of activities for: increasing the share of closed-loop productions; accelerated development of the processing agro-industrial complex' branches, large-scale agriculture (primarily animal husbandry), science-intensive industries in the mechanical engineering, aircraft construction and instrumentation, communications and telecommunications; forming the regional clusters specialized in services and recreation, innovation infrastructure and applied research, maintaining transit passenger traffic through international transport corridors; preferential lending for housing construction;

- the use of the socio-cultural sectors' potential (education, science and scientific services, specialized medical care, sanatorium and resort treatment) in diversifying and improving the competitiveness of regional economies and settlement systems;

- the implementation of programs for accelerating innovative modernization and increasing the national economy' technological independence, stabilizing labor supply and demographic situation in regions and settlement systems;

- the expansion of the internal consumer market, optimization of proportions "production - consumption", "consumption - accumulation";

- the provision of an effective and secure specialization (in the national interests' context, including requirements for economic, social, environmental safety) of the special economic zones and trans-boundary regions;

- the assistance in the development of foreign markets for domestic goods and services, including through the involving the foreign economic activity' infrastructure, deepening humanitarian relationships, joining the interstate structures; 


\section{Bogush Larysa}

- the normative regulation of the problem territories' justified classification, improvement of the methods' efficiency for their determination, as well as the selection quality of monitoring indicators in the process of their rehabilitation; coordination and definition of the rehabilitation measures' pace according to the type of specific problem area;

- the selection and programming of the development of target territories integrating spatially close problem regions and leading regions "locomotives".

The system of special measures for the removal of depressive territorial tensions (sanitation) must simultaneously influence the situation in the economy, socio-political relations, nature management, environmental protection and other spheres of life; thus, it requires the use of individually directed multifunctional economic and legal, socio-organizational, socio-economic and demographic, as well as other types of regulators, combined with transfers as the general instrument for the territorial development' state regulation.

According to the options for rehabilitation (temporary preservation of a de-pressed situation as an obstacle to further destruction without eliminating its causes due to the necessary resources' lack, restructuring with the transforming of economic potential, solving social problems, eliminating environmental threats and dangers, etc.; formation of a special economic mode), the mechanisms of the corresponding measures include: the selection of specific sanitation objects in the specialization sectors, as well as in the infrastructure and personnel provision of their activities, etc.; the targeted state and program investment, an attraction of private investments on the basis of tax privileges, fiscal vacations, etc.; the support for certain forms and types of economic activity (for example, small businesses, farmers, co-operation of enterprises, their corporatization by labor collectives); the intensification of productive employment, economically feasible migrations and entrepreneurial initiatives of the population, including promoting the new workplaces establishment, finding an effective owner, diversifying the economic spheres in accordance with the local resource potential, etc.; the improvement of the economy' infrastructure and human resources (through the targeted development of the road and transport network, systems of energy supply and communications, spheres of vocational education, scientific services and innovation activities, etc.). 
Measures for the integration of spatially close problem regions and regions - "locomotives", aimed at eliminating significant structural and social differences in their development, in particular, consist of: the implementing the state and regional programs for development and increase of the production and social infrastructure' accessibility of both regions; the stimulating their joint participation in: the partial financing of a number of infrastructure facilities designed to improve transport accessibility and engineering arrangement of the problem region' settlement system; providing the needs of the territorial labor markets; raising the level of the resource potential development and management in the problem region; the subsidizing the problem region' social expenditures to the level of their provision in the region - "locomotive" with the joint participation of the state and relevant macro-regional (oblast) budgets.

\section{Approaches to increasing the Ukrainian regions' competitiveness on the basis of the socio-humanitarian resources' systematic capitalization}

The functions of the spectrum of social capital' subsystems (human, intellectual, innovative, communicative, organizational, interface) in the economy determine the main directions of their improvement in the context of the Ukrainian regions' competitiveness increase, among which we should mention about: improving the availability of the information' sources and channels for separate individuals, socium groups, society as a whole; investing in the process of the innovations' disseminating and stimulating the demand for them; expanding the economic entities' innovative and rent-forming potential, creating the conditions for its realization; improving the motivations' structure of individuals (in particular, on labor, productive employment, employee performance) and business entities; rationalizing the transaction costs associated with mechanisms for conducting and coordinating economic, entrepreneurial and innovative activities; promoting the business' social responsibility; optimizing the institutional structure of all society's life spheres.

The development of the human and intellectual components of the Ukrainian regions' social capital primarily involves: the improvement of tangible grounds of the population well-being; the efficiency increase of structural adjustment, technical and technological modernization of the economic complex.

The implementation of the first of aforementioned main directions should be carried out on the principles of: 


\section{Bogush Larysa}

- observing the proportionality and consistency in the economic, social, innovative and ecological sub-systems of regional policy;

- approving and observing a set of social standards and guarantees as the basis for the development of the state social protection system that implements the social state grounds; applying these standards and guarantees in the calculations of wages, pensions and other social payments, prices and tariffs for goods and services, expenditures of the different levels' budgets, as well as in determining the material, financial, labor needs of regional economic complexes;

- harmonizing a subsistence level, minimal salary and pension with social standards and guarantees, improving the mechanisms for indexing wages and social benefits;

- systemizing and strengthening the financial support for measures to combat poverty, implement the employment guarantees, reduce unemployment, provide socio-economic support to young people, young families and families with children, increase the availability of socially necessary services for vulnerable strata;

- implementing active social protection programs aimed at revitalizing the initiative of low-income and unemployed categories in the field of vocational training and retraining, getting a job, starting their own business, participating in public works, etc.;

- implementing the mechanism for providing graduates of the vocational technical and higher education institutions with the first job; promoting the development of the system of the personnel vocational training in the workplace by: the fiscal stimulation of employers to finance such activity; the workers' motivation through the labor remuneration policy;

- forming the effective mechanisms of the influence of consumers and civil society structures on the social sector functioning, including the processes of financing, control and adjustment of the services' quality within the satisfaction of the household, social and cultural needs of individuals, mass consumers' different categories and territorial communities.

In turn, the efficiency' increasing of the structural adjustment, technical and technological modernization of the economic complex (as another main direction for development of the human and intellectual components of the regional social capital) is based on:

- the transition to integrated regional educational systems oriented to satisfy local staffing needs, improve the mechanism and strengthen the 
incentives of sustainable socio-economic development, increase the region' competitiveness; the improvement of the using efficiency of the education system' resource potential due to its concentration in the regional resource centers established on the basis of the leading regional educational institutions according to its economy' priority sectors and designed to disseminate innovative activity to other educational, scientific institutions and business entities of all ownership forms;

- the increase of the R \& D economic efficiency on the principles of integrating education, science and production, stimulating the formation of elements and integral territorial systems of innovation development through deepening cooperation between educational and scientific institutions, establishing technology parks, research consortia, business incubators, etc.;

- the substantial increase in the share of science-intensive, high-tech and re-source-saving types of economic activity in the service sector (primarily in scientific and IT services, services for ensuring the market functioning, household services for the population, financial and insurance services, services for tourism, recreation and entertainment); the further legal regulation, acceleration of the turnover sphere development, provision for the proper control over maintaining its standards (in particular, in the trade, restaurant business);

- the further regulatory and legal settlement of the problems of realizing the intellectual (creative, knowledge generating, rent-forming) potential of the economically active population;

- the promotion of the further small and medium-sized businesses' expansion in the services sector, stimulation of the innovative infrastructure development;

- the innovative activity' intensification, increase of the business entities' in-vestment attractiveness in the social sphere' export-oriented segments (vocational education, inbound recreational industry, highly specialized medical services, applied R \& D); growth of the international and, in particular, cross-border relations in science, education, culture, tourism;

- the development of tourism and recreation as the specialization sectors of the Ukraine' regions in the international labor division, in particular, by improving the investment climate in the recreation and entertainment industry, increasing the mechanisms efficiency for regulating the quality and prices for tourist, excursion, sanatorium, resort and hotel services, enhancing their information and advertising support on the foreign market; 


\section{Bogush Larysa}

- the priorities selection and forecasts justification for the development of regional tourist and recreational spheres, collaboration coordination of the local authorities and business entities implementing relevant goals; conduction of the investment policy aimed at the regional tourist brands' formation and specific integrated tourism products' market promotion; encouragement of the entrepreneurial activity in the regional tourist and recreational sphere, as well as the new workplaces' creation in the branches associated with this industry; implementation of the programs for the social infrastructure development to ensure the tourists' cultural and household needs;

- the acceleration of the open information society' development on the basis of creating infrastructure networks (including electronic ones) for providing the unified national scientific and educational information space' functioning, integrated into relevant supranational and other international structures.

Adaptation of the above-mentioned measures for expanding the human and creative (intellectual, innovative) components of the Ukrainian regional socio-humanitarian potential and increasing their capitalization efficiency at the local level, in particular, requires: the implementation of the rules and standards for determining the developers' fees for share participation (contributions) in ensuring the proper level of the social infrastructure complexity, working out their payment mechanisms to the local budgets; the local authorities' participation in preparing the government orders for the commercial production of the socially necessary goods and services; the licensing of the utilities services' producers, as well as controlling over their contractual obligations' fulfillment; stimulating the implementation of effective energy-saving technologies for building and exploitation of housing stock and utilities engineering infrastructure; the provision of the social protection services for vulnerable categories' consumers according to their current standards; the involvement of financial instruments (benefits, guarantees, subsidies) in order to assist in obtaining loans for local economic entities in the tourist and recreational industry; the implementation of programs for improving resort and other types of recreation zones, as well as for maintaining public order in these territories.

In the context of diversifying the economy of the leading, less developed and depressed Ukrainian regions, strengthening its science-intensity and postindustrial orientation, increasing the innovative and technological 
progress' efficiency, improving the population' life quality, it is expedient to allocate the following "growth points", such as:

- tourism, in particular by:

- strengthening the positions in the separate segments of the tourist services' international market (first of all in the long-term resort entertainment, sanatorium treatment, cultural-educational, sports-treatment, business, educational and rural green tourism) with further dynamic progress towards obtaining the status of the "active tourist" country, aimed at incorporating the tourism industry into the national economic complex' specialization sectors and gaining strong positions on the tourist and recreational services' world market (the important indicator of this position is the tourist contingent' proportion, when the foreign tourists' number exceeds the trips' number of the own citizens abroad);

- vocational education, sphere of applied research and development, in particular by:

- increasing the presence on the professional and postgraduate education ser-vices' international market due to the rising their volume provided to foreign citizens by higher educational and research institutions (of the NAS system);

- improving the presence on the science-intensive products' international market through the applied research intensification in Ukraine, implementation of institutional conditions for increasing the cooperation efficiency of science and education (due to the: formation of regional venture production clusters on the basis of leading universities of national importance; further development of a network of industrial parks and technopolises in free economic zones, border and trans-boundary regions), adjustment of regulations in the field of intellectual property, copyright and related rights in the compliance with international norms;

- specialized medical care, sanatorium and resort treatment, activities in medical innovations, in particular by:

- expanding the presence on the medical services, goods and technologies' international market, growing their export volumes, including through: the provision of the appropriate competitiveness of export-oriented products of the national medical and pharmaceutical industry according to international standards; the fulfillment of state programs implementing the achievements of domestic specialists and scientific schools in the modern diagnosis, treatment and prevention technologies, as well as research results 


\section{Bogush Larysa}

in various fields of medicine, genetics, biochemistry, biotechnology, etc.; the enrichment of the foreign potential consumers' awareness regarding the services' quality of leading domestic medical centers, sanatorium and resort treatment areas in order to promote their international recognition;

- developing the international cooperation in the healthcare, including through the provision of specialized humanitarian assistance to developing countries and countries affected by ecological and technogenic disasters.

\section{Conclusions}

The balance of regional policy for reproduction and efficient capitalization of the socio-humanitarian potential should be achieved through the implementation of the quantitative and qualitative state obligations regarding: the ensuring a decent level and a safe living environment of the population; stimulation of its productive employment at the place of residence, in conjunction with the improvement of the internal labor migrations' efficiency; intervention in the development of regions and local communities in order to prevent, smooth and equalize territorial socio-economic disparities, to decentralize and adapt general foundations, principles and means for providing state socio-economic policy at the local level, to optimize the reverse regional influences on the whole country' activity in response to the negative dynamics of the relevant monitoring indicators' system.

Considering the mechanism of social reproduction, which allows to stimulate self-development through the satisfaction of the widest range of the population' socially necessary needs, the important role in the Ukrainian regional policy (following the example of the world' leading countries) should be given to its social component, which primarily consists from the measures for: the regulation of the local economic systems' labor supply; the increase of realization efficiency of the economically active population' innovative potential in the process of expansion of its productive employment sphere; the support of inter-ethnic and inter-confessional stability within the local and regional territorial communities.

It is expedient to monitor and to correct the results of the implementation of the government strategy for Ukraine' regional development according to the indicators of: the life level of the population in regions and settlements, as well as satisfying its socially necessary needs and ensuring constitutional rights and freedoms (including freedom of speech, political and religion choices); the employment level, competitiveness in the labor market and 


\section{Balancing socio-economic development of Ukraine' regions on the priority...}

entrepreneurial activity of the population (including organizational, regulatory and investment climate in the field of realization of citizens' entrepreneurial initiatives); the peculiarities of formation and structure of income, property stratification; the situation in the areas of environmental protection and maintaining national security (including in the directions for prevention of socially dangerous diseases, criminality); the resource potential and implementation efficiency of the state and local authorities' social functions, the level of development and functioning efficiency of the territorial communities, the social partnership mechanisms' formation; the implementation of complex and sectoral programs, as well as targeted projects in the areas of living environment' improving.

\section{References:}

1. Babinova, O. (2009). Reghionaljna polityka jak predmet naukovoteoretychnogho analizu [Regional policy as a subject of scientific and theoretical analysis]. Visnyk Nacionaljnoji akademiji derzhavnogho upravlinnja [Bulletin of the National Academy of Public Administration]. Retrieved from: http://visnyk. academy.gov.ua/wp-content/uploads/2013/11/2009-3-19.pdf(accessed 10.03.2018) (in Ukrainian).

2. Bogush, L. (2017). Socio-humanitarian potential of Ukraine's competitiveness worldwide. Transformation of international economic relations: modern challenges, risks, opportunities and prospects. Riga: ISMA University, pp. 103-112.

3. Boretska, N.P. (2005). Vyshcha osvita v konteksti sotsialnoi polityky derzhavy [Higher education in the context of state social policy]. Novi tekhnolohii navchannia [New Learning Technologies], no. 40, pp. 4-10 (in Ukrainian).

4. Hordei, O.D. (2003). Modeli derzhavnoho rehuliuvannia dobrobutu naselennia [Models of state regulation of the population welfare]. Finansy Ukrainy [Finance of Ukraine], no. 11, pp. 51-57 (in Ukrainian).

5. Zgurovsky, M.Z., Gavrish, O.A., Skorobogatova, N.Ye., \& Kukharuk, A.D. (2018). Zabezpechennia sotsialno-ekonomichnoho balansu rehionalnoho rozvytku Ukrainy [Providing the social and economic balance of Ukraine's regional development]. Ekonomika ta derzhava [Economy and the State], no. 2, pp. 11-15 (in Ukrainian).

6. Luchyk, S.D., \& Luchyk, V.Ye. (2013). Svitovyi dosvid formuvannia ta realizatsii polityky rehionalnoho rozvytku ta mozhlyvist yoho zaprovadzhennia $\mathrm{v}$ Ukraini [World experience of formation and realization of regional development policy and the possibility of its implementation in Ukraine]. Naukovyi visnyk Natsionalnoho lisotekhnichnoho universytetu Ukrainy [Scientific herald of the National Forestry University of Ukraine]. Retrieved from: http://nltu.edu.ua/nv/ Archive/2013/23 18/124_Lucz.pdf (accessed 10.03.2018) (in Ukrainian).

7. Libanova, E.M. (ed.) (2012). Liudskyi rozvytok v Ukraini: sotsialni ta demohrafichni chynnyky modernizatsii natsionalnoi ekonomiky [Human development in Ukraine: social and demographic factors of the national economy' 
modernization]. Kyiv: Ptoukha Institute for Demography and Social Studies of the National Academy of Sciences of Ukraine, 320 p. (in Ukrainian).

8. Martinenko, O.M. (2017). Napriamy zabezpechennia zainiatosti molodi v rovynutykh krainakh [Directions for promoting youth employment in developed countries]. Ekonomika ta derzhava [Economy and the State], no. 12, pp. 74-76 (in Ukrainian).

9. Ogienko, M.M., \& Gurina, O.V. (2018). Doslidzhennia stanu ta tendentsiinykh transformatsii liudskoho potentsialu $\mathrm{v}$ rehioni [Study of state and trending transformations of human capacity in the region]. Ekonomika ta derzhava [Economy and the State], no. 2, pp. 103-107 (in Ukrainian).

10. Petkova, L.O. (2004). Klasterna model haluzevo-terytorialnoi orhanizatsii vyrobnytstva yak peredumova yoho innovatsiinoi aktyvizatsii [Cluster model of the production' branch-territorial organization as a background for its innovation activation]. Nauchnye trudy Donetskogo natsional'nogo tekhnicheskogo universiteta. Seriya: Ekonomika [Scientific works of Donetsk National Technical University. Series: The Economy], pp. 97-102 (in Ukrainian).

11. Prokopiuk, A. (2015). Derzhavna rehionalna polityka: naukovi pidkhody ta svitovi praktyky [State regional policy: scientific approaches and world practices]. Sotsialno-ekonomichni problemy suchasnoho periodu Ukrainy [Socio-Economic Problems of the Ukraine' Modern Period]. Retrieved from: http://ird.gov.ua/sep/ sep20156(116)/sep20156(116)_014_ProkopiukA.pdf (accessed 10.03.2018) (in Ukrainian).

12. Pulina, T.V. (2017). Suchasni aspekty ta metody upravlinnia ryzykamy innovatsiinykh proektiv v Ukraini [Modern aspects and methods of risk management of innovative projects in Ukraine]. Ekonomika ta derzhava [Economy and the State], no. 10, pp. 4-8 (in Ukrainian).

13. Dolishnii, M.I. (ed.) (2001). Rehionalna polityka: metodolohiia, metody, praktyka [Regional policy: methodology, methods, practice]. Lviv: Institute for Regional Studies of the National Academy of Sciences of Ukraine, $720 \mathrm{p}$. (in Ukrainian).

14. Sofiichuk. K.K. (2017). Pidvyshchennia turystychnoi pryvablyvosti Ukrainy [Increasing the tourist attractiveness of Ukraine]. Ekonomika ta derzhava [Economy and the State], no. 10, pp. 63-66 (in Ukrainian).

15. Chupryna. O.O. (2011). Sotsialna nerivnist i bidnist v Ukraini [Social inequality and poverty in Ukraine]. Visnyk Natsionalnoi yurydychnoi akademii Ukrainy imeni Yaroslava Mudroho [Bulletin of the Yaroslav Mudryi National Law Academy of Ukraine], no. 2 (5), pp. 57-66 (in Ukrainian). 